\title{
THE EFFECTIVENESS OF PREDICT-OBSERVE-EXPLAIN TECHNIQUE IN PROBING STUDENTS' UNDERSTANDING ABOUT ACID-BASE CHEMISTRY: A CASE FOR THE CONCEPTS OF PH, POH, AND STRENGTH
}

Received: 3 August 2011; Accepted: 20 June 2012

\begin{abstract}
The present study describes high school students' conceptions about acids and bases in terms of $\mathrm{pH}, \mathrm{pOH}$, microscopic level, strength, and concentration. A total of 27 high school students participated in the study. The data was collected using 3 POE tasks and a semi-structured interview. The data analysis demonstrated that most of the students had poor understanding related to a drawing of weak and strong acids. In addition, the findings revealed that the POE's were effective in terms of gathering students' predictions and reasons for the prediction of outcomes in an open-ended format. The POE tasks also revealed that some of the students had misconceptions regarding $\mathrm{pH}$ and $\mathrm{pOH}$. The students believed that $\mathrm{pH}$ was a measurement of the acidity, while $\mathrm{pOH}$ was a measurement of the basicity. The findings obtained have certain implications for the secondary chemistry program.
\end{abstract}

KEY WORDS: assessment, misconceptions, $\mathrm{pH}, \mathrm{POE}, \mathrm{pOH}$, strength

\section{INTRODUCTION}

In any teaching or learning approach enlightened by constructivism, it is important to infer the students' ideas of what is already known (Driver \& Scott, 1996). These ideas can sometimes be different from the commonly accepted scientific knowledge, which is mostly referred to as a misconception or an alternative conception. As students come to classes with their own ideas related to the natural world, the instructors should be aware of the students' previous knowledge to plan their subsequent learning experiences, which in turn helps to facilitate meaningful learning (Kearney \& Treagust, 2001; Kearney, 2004). Therefore, it is important to determine the students' misconceptions.

For many decades, there have been a number of studies that reported the students' misconceptions related to different scientific concepts, such as equilibrium (Banerjee, 1995; Gussarsky \& Gorodetsky, 1990), particulate nature of matter (Abraham, Williamson \& Westbrook, 1994; Griffiths \& Preston, 1992; Ayas, Özmen \& Çalık, 2010), electrochemistry (Garnett \& Treagust, 1992), and chemical bonding (Coll \& Treagust, 2003). 
The subject of acids and bases is an important topic in the chemistry curriculum of middle and upper high schools and the general chemistry courses at universities. In this context, acids and bases have included biological activities, those causing environmental problems, as well as those that have become very common in everyday life. Therefore, acidbase chemistry is being taught at different education levels such as primary school, high school, and university.

Thus, like other chemistry topics, several research studies have reported certain alternative conceptions relevant to acids and bases (Boz, 2009; Bradley \& Mosimege, 1998; Cros, Maurin, Amouroux, Chastrette, Leber \& Fayol, 1986; Demircioglu, Ayas \& Demircioglu, 2005; Lin, Chiu \& Liang, 2004; Nakhleh \& Krajcik, 1994; Ross \& Munby, 1991; Schmidt, 1991, 1995; Sheppard, 1997, 2006). Techniques, such as concept maps, word association tests, the predict-observe-explain technique (POE), interviews about concepts and events, student journals and diagnostic multiple-choice tests have been used to probe student understanding (Duit, Treagust \& Mansfield, 1996; White \& Gunstone, 1992; Kearney, 2004). The present study utilized POE tasks and interviews to probe the students' understanding.

The POE strategy has been used for eliciting students' understanding (Kearney, 2002, 2004), determining students' alternative conceptions (Champagne, Klopher \& Anderson, 1980; Gunstone, Champain \& Klopfer, 1981), and promoting conceptual understanding (Tao \& Gunstone, 1999). However, there have been limited studies related to evaluating students' responses given to the POE tasks. Hence, this study will contribute in terms of the analyzing of POE tasks as well as students' understanding about acid-base chemistry. In this context, the purpose of the present study is to investigate the Turkish High School students' conceptions related to acids and bases under three headings: (a) the concept of $\mathrm{pH}$ and $\mathrm{pOH},(\mathrm{b})$ microscopic understanding of strong and weak acids, and (c) differences between the strength and concentration of acids and bases. Accordingly, the literature review will be discussed under the above mentioned three headings.

\section{$p H$ and $p O H$}

While limited reported information related to $\mathrm{pOH}$ is available in the literature, there has been some information related to the $\mathrm{pH}$ concept. The study by Banerjee (1991), which was implemented with high school chemistry teachers and undergraduate chemistry students, reported that most of the students had certain incorrect ideas related to the $\mathrm{pH}$ concept 
and concentration. The students stated that even though a strong and a weak acid had the same concentration, the $\mathrm{pH}$ of the weak acid could be the same $\mathrm{pH}$ as the strong acid. Cros et al. (1986) noted that undergraduate students' descriptive definition for $\mathrm{pH}$ demonstrated little change, while comparing their explanations with a previous study. While Bradley \& Mosimege (1998) established that prospective teachers had some difficulties in understanding the $\mathrm{pH}$ function, even though their understanding of $\mathrm{pH}$ and acidity was relatively good, Ross \& Munby (1991) revealed that high school students showed a good understanding of the pH concept. Schmidt (1995) reported that grammar school (Gymnasium) students in Germany were aware that every neutralization reaction resulted in a neutral solution because of the term "neutralization" that acted as a hidden persuader. In addition, the students also decided that the products of every neutralization reaction had a $\mathrm{pH}$ of 7 . In addition, Pınarbaşı (2007) revealed that the Turkish undergraduate students had some misconceptions, such as that the "pH of an acid solution that is excessively diluted could be over 7." Nakhleh \& Krajcik (1994) reported that some of the high school students established certain unacceptable relations, such as "the $\mathrm{pH}$ is inversely related to being harmful."

\section{Microscopic Understanding of Strong and Weak Acids}

The macroscopic, microscopic, and symbolic levels have been used to facilitate teaching the chemical events to the students. The macroscopic levels include the events which are observable, while the microscopic levels explain using the idea of molecules and atoms. The symbolic levels are shown through the use of symbols, numerically, equations, etc. In this context, it has been established that the students can meaningfully construct their chemistry knowledge when they imagine the concepts at the microscopic level. Besides, they can also conceptualize their other knowledge and establish a suitable relationship between the concepts (Ebenezer, 2001; Özmen, Ayas \& Coştu, 2002; Raviola, 2001). In this context, it is important to determine the students' microscopic understanding.

There have been a limited number of studies reported in literature related to the microscopic level of strong acids and bases (Nakhleh, 1994; Smith \& Metz, 1996). In a study which analyzed the students' drawings as to the particulate nature of matter, Nakhleh (1994) reported that most students' understanding was not adequate in relation to acid-base chemistry. Besides, most students were unable to make connections 
between the different representational levels, such as the macro, micro, and symbolic level. The study carried out by Smith \& Metz (1996) tested the undergraduate students' as well as the faculty's understanding of acid strength and solution chemistry. In the above-mentioned study, the students were required to select the best representation of $\mathrm{HCl}$ and $\mathrm{HF}$ and were also asked to draw some microscopic representation of the chemical reaction, such as the reaction of $\mathrm{NiCl}_{2}$ with $\mathrm{NaOH}$. It was established that many students believed that the strong acids had strong bonds while the weak acids had weak bonds. Thus, acids could be easily separated into pieces. Besides, the students had some misconceptions regarding the bonding as well as some misunderstandings related to the solubility and the dissociation process, even though they could balance the equation.

\section{Differences Between Strength and Concentration of Acids and Bases}

Sheppard (2006) stated that the high school students in the sample described $\mathrm{pH}$ as a measurement of strength and understood that the more acidic solutions had a lower $\mathrm{pH}$. Boz (2009) noted that a majority of the student teachers related the acid strength to the hydrogen ion concentration, even though they were not aware of the discrepancies between the concentration and the strength of an acid. In addition, Ross \& Munby (1991) found that high school students had sufficient information related to concentration and made a distinction between a strong acid and a weak acid. However, the students stated that the strong acids had strong bonds when compared with the weak acids. Lin, Chiu \& Liang (2004) reported that the high school students in Taiwan believed that the strength of an acid was related to the number of hydrogen atoms in the molecule formula.

\section{The Methodology}

The present study used a case study because it enables the giving of permission to make a searching investigation of an event, a fact, a situation, and an individual or a group (Bassey, 1999; Stake, 1995; Yin, 1994).

\section{The Sample}

The sample in the present study consisted of 27 high school students who were enrolled in the science and mathematics track in an Anatolian high school in Trabzon, Turkey. The selected sample first studied the acid and 
base subject in the middle school (grades $6-8$ ) in the eighth year. Later, the acid and base topic was studied in high school. The present study was implemented, based on the sample that completed the normal instruction on the acid and base topic. The treatment was carried out individually with the sample by using worksheets.

\section{Instruments}

POE tasks and semi-structured interviews were used to determine the students' understanding of the $\mathrm{pH}-\mathrm{pOH}$ concepts and the strength of the acids. Two different instruments were used to obtain internal validity, as well as the reliability of the study.

\section{POE}

POE tasks probe the students' understanding using three different but related sequences, such as prediction, observation, and explanation (White \& Gunstone, 1992). In the first sequence, the students are required to predict an outcome of an event, such as the sequence of $\mathrm{pH}$ and $\mathrm{pOH}$ for certain acids and bases and to also justify their prediction. In the second sequence, which is the required observation of the event, the students observe or perform the event, such as observing the $\mathrm{pH}$ of a certain acid and base using litmus paper. In the last sequence, the students have to reconcile their prediction and observation to find out whether there are any differences between the two (White \& Gunstone, 1992).

Brief Description of POE Implementation. Before starting the POE implementation, students were given information about the POE sequences. Students were told that they would perform an experiment and then be asked to write their predictions, along with reasons. Then they would observe the experiment. Finally, they would comment on any discrepancies between their prediction and their observation.

In the first task, the students were asked to predict the sequence of $\mathrm{pH}$ and $\mathrm{pOH}$ of lemon, $1 \mathrm{M} \mathrm{HCl}$, and tap water. In the second task, the students were asked to predict the sequence of the $\mathrm{pH}$ and $\mathrm{pOH}$ of soap, $1 \mathrm{M} \mathrm{KOH}$, and tap water. Finally, in the third sequence, the students were requested to predict the $\mathrm{pH}$ of $10 \mathrm{ml}$ of $\mathrm{HCl}$, which was diluted from $1 \mathrm{ml}$ $1 \mathrm{M} \mathrm{HCl}$. As well, the students were also asked whether there was any change in the $\mathrm{pH}$ of the $\mathrm{HCl}$ before and after the dilution. Worksheets were then distributed to the students to write their prediction, the reason for their prediction, observations, and then discrepancies between the prediction and observations. 


\section{Interviews}

The interview technique probes the students' understanding using certain questions related to the understanding of an event, phenomena, or concept. The semi-structured interview technique was used in the present study. After completing the POE tasks, the students' POE worksheets were examined. The students were then divided into three groups: low, medium, and high levels in terms of their prediction and explanation of the written answers in the worksheets. A total of six students, two each at the low, medium, and high achievement levels, were interviewed in relation to the concepts given to them. The students were questioned about their concepts of $\mathrm{pH}, \mathrm{pOH}$, as well as some items related to acids and bases, such as "What is pH?," "What is $\mathrm{pOH}$ ?," "What can you say about the $\mathrm{pH}$ of a strong acid?," "What can you say related to a solution whose $\mathrm{pOH}$ is 9 ," etc. In addition, students were asked some questions related to the written answers for the POE tasks. Moreover, during the interview procedure, students were given a paper and pencil and requested to draw at the microscopic level of some of the concepts. The interviews were carried out for $20-25$ min with each student. All the interviews were audio-taped and transcribed. Different data instruments were used to obtain the validity and reliability for the study.

\section{Analysis of Data}

\section{Analysis of the POE Tasks}

Although there has been no reported analyzing procedure for the POE, in this study, a different analyzing approach was offered taking into account students' level of understanding, which is similar to the literature as used by Abraham et al., 1992. Data gathered from the written responses to the POE tasks were analyzed and divided into six groups. In this context, while students' prediction were divided into two categories as being correct or wrong, reasons for predictions were divided into three categories as being correct, partially correct, or wrong. An example of the analysis of the first POE task is given in Table 1.

\section{Analysis of Semi-structured Interview}

Interviews were analyzed using the content analysis technique. The purpose of this technique is to obtain the concepts and relationships, which explain the gathered data (Yıldırım \& Şimşek, 2006). While the 
TABLE 1

Analyzing of the first POE

\begin{tabular}{|c|c|c|c|}
\hline Category & Explanation of category & Prediction & The reason for the prediction \\
\hline CP-CERP & $\begin{array}{l}\text { Correct explanation } \\
\text { for the reason of the } \\
\text { prediction }\end{array}$ & $\begin{array}{l}\mathrm{pH}_{\text {tapwater }}> \\
\mathrm{pH}_{\text {Lemon }}>\mathrm{pH} \mathrm{HCI} \\
\mathrm{pOH}_{\mathrm{HCI}}> \\
\mathrm{pOH}_{\text {Lemon }}>\mathrm{pOH}_{\text {tapwater }}\end{array}$ & $\begin{array}{l}\text { " } \mathrm{HCl} \text { which has } 1 \mathrm{M} \text { has } \\
\text { the smallest } \mathrm{pH} \text {; the } \mathrm{pH} \\
\text { of tap water is very close } \\
\text { to } \mathrm{pH} 7 \text {, and lemon is a } \\
\text { weak acid and its } \mathrm{pH} \text { is } \\
\text { between the others" }\end{array}$ \\
\hline CP-PCERP & $\begin{array}{l}\text { Correct prediction } \\
\text { Partially correct } \\
\text { explanation for reason } \\
\text { of prediction }\end{array}$ & $\begin{array}{l}\mathrm{pH}_{\text {tapwater }}> \\
\mathrm{pH}_{\text {Lemon }}>\mathrm{pH}_{\mathrm{HCI}} \\
\mathrm{pOH}_{\mathrm{HCI}}>\mathrm{pOH}_{\text {Lemon }}> \\
\mathrm{pOH}_{\text {tapwater }}\end{array}$ & $\begin{array}{l}\text { "Tap water is a weak acid, } \\
\text { so its } \mathrm{pH} \text { is the highest. } \\
\mathrm{HCl} \text { is a strong acid and } \\
\text { that is why the smallest } \\
\mathrm{pH} \text { will belong to it. The } \\
\mathrm{pH} \text { of lemon is between } \\
\text { the two of them. The } \\
\text { sequence of pOH is the } \\
\text { inverse of the pH sequence" }\end{array}$ \\
\hline CP-WERP & $\begin{array}{l}\text { Correct prediction } \\
\text { Wrong explanation } \\
\text { for reason of prediction }\end{array}$ & $\begin{array}{l}\mathrm{pH}_{\text {tapwater }}> \\
\mathrm{pH}_{\text {Lemon }}>\mathrm{pH}_{\mathrm{HCI}} \\
\mathrm{pOH}_{\mathrm{HCI}}>\mathrm{pOH}_{\text {Lemon }}> \\
\mathrm{pOH}_{\text {tapwater }}\end{array}$ & $\begin{array}{l}\text { " } \mathrm{pH}_{\text {tap water }} \text { is neutral or } \\
\text { close to } 8 \text { (a drop of water); } \\
\text { lemon is sour, but it is not } \\
\text { burning. As far as I know } \\
\mathrm{HCl} \text { is more searing, when } \\
\text { you touch it it can damage you" }\end{array}$ \\
\hline WP-CERP & $\begin{array}{l}\text { Wrong prediction } \\
\text { Correct explanation } \\
\text { for reason for the } \\
\text { prediction }\end{array}$ & $\begin{array}{l}\text { There have not been any } \\
\text { available students' } \\
\text { answers } \\
\text { for this category }\end{array}$ & $\begin{array}{l}\text { There have not been any } \\
\text { available students' answer } \\
\text { for this category }\end{array}$ \\
\hline $\begin{array}{l}\text { WP- } \\
\text { PCERP }\end{array}$ & $\begin{array}{l}\text { Wrong prediction } \\
\text { Partially correct } \\
\text { explanation for reason } \\
\text { for the prediction }\end{array}$ & $\begin{array}{l}\mathrm{pH}_{\mathrm{HCI}}>\mathrm{pH}_{\text {lemon }}> \\
\mathrm{pH}_{\text {tapwater }}>\end{array}$ & $\begin{array}{l}\text { "Water is approximately } \\
\text { neutral. } \mathrm{HCl} \text { is a very } \\
\text { extremely strong acid. Lemon } \\
\text { juice also includes acid, but } \\
\text { its acidity is not strong. If lemon } \\
\text { had strong acidity, we would } \\
\text { not eat it. pOH is the opposite } \\
\text { of pH" }\end{array}$ \\
\hline WP-WERP & $\begin{array}{l}\text { Wrong prediction } \\
\text { Wrong explanation } \\
\text { for the reason for the } \\
\text { prediction }\end{array}$ & $\begin{array}{l}\mathrm{pH}_{\text {Lemon }}> \\
\mathrm{pH}_{\text {tapwater }}=\mathrm{pH}_{\mathrm{HCI}} \\
\mathrm{pOH}_{\mathrm{HCI}}=\mathrm{pOH}_{\text {tapwater }}> \\
\mathrm{pOH}_{\text {Lemon }}\end{array}$ & $\begin{array}{l}\text { " } \mathrm{H}_{2} \mathrm{O} \text { has } 1 \mathrm{M} \text { and } \mathrm{HCl} \text { also } \\
\text { has } 1 \mathrm{M} \text {. So, their } \mathrm{pH} \text { and pOH } \\
\text { is equal. The pH of lemon is } \\
\text { smaller than } 8 \text {, which means the } \\
\text { pH of lemon is higher than tap } \\
\text { water and molarity of } \mathrm{HCl} \text { " }\end{array}$ \\
\hline
\end{tabular}

CP-CERP: correct prediction-correct explanation for reason for prediction, $C P-P C E R P$ correct prediction-partially correct explanation for reason for prediction, $C P$-WERP correct prediction-wrong explanation for reason for prediction, $W P-C E R P$ wrong prediction-correct explanation for reason for prediction, WP-PCERP wrong prediction-partially correct explanation for reason for prediction, WP$W E R P$ wrong prediction-wrong explanation for reason for prediction 
students' interviews were analyzed, their names were coded as A, B, C, $\mathrm{D}, \mathrm{E}$, and $\mathrm{F}$ to protect the students' identities for the purpose of confidentiality.

\section{Findings}

The findings obtained from analyzing the POE tasks, drawings, and interviews are presented below.

\section{Findings Related to POE Tasks}

Findings Related to the First POE Task. For the first POE task, the students were required to make a prediction related to the sequence of the $\mathrm{pH}$ and $\mathrm{pOH}$ for certain substances, such as tap water, lemon, and $\mathrm{HCl}$. It was anticipated that the students could establish the sequence of $\mathrm{pH}_{\text {tap }}$ water $>\mathrm{pH}_{\mathrm{Lemon}}>\mathrm{pH}_{\mathrm{HCI}}$, as well as the sequence for $\mathrm{pOH}$, which is the reverse of the sequence of $\mathrm{pH}$. Besides, the students must also explain their predictions and the reasons correctly. While 21 of the 27 students made a correct prediction of the sequence of the $\mathrm{pH}$ and $\mathrm{pOH}$, only one of the students could give a correct explanation for the reason for the prediction. Six of the students made wrong predictions, while four of them explained using partially correct reasons for the prediction. The section below demonstrates the students' misunderstandings as well as the alternative statements related to the concepts under consideration in the present research:

The lowest $\mathrm{pH}$ might belong to the solution of $\mathrm{HCl}$ because it is a strong acid. The sequence of the $\mathrm{pH}$ of lemon juice will come just after the solution of $\mathrm{HCl}$ because it is also acidic. The $\mathrm{pH}$ of tap water might be acidic, basic or neutral. I did the above sequence because the higher $\mathrm{pH}$ of a solution gets a lower $\mathrm{pOH}$

$\mathrm{HCl}$ shows a completely acidic character as this can be easily understood from its name hydrochloric acid. Therefore, it has a higher $\mathrm{pH}$. The $\mathrm{pH}$ of water is nearly neutral because of its harmless nature. And the substance that has a higher $\mathrm{pH}$ has a lower $\mathrm{pOH}$.' 'Water is close to neutral. $\mathrm{HCl}$ is a very strong acid, lemon has acid, but its acidic character is not as strong as $\mathrm{HCl}$. If lemon juice had strong acidity, we could not eat it. The sequence of pOH is the opposite of $\mathrm{pH}$,' ' $\mathrm{H}_{2} \mathrm{O}$ is $1 \mathrm{M}$ and $\mathrm{HCI}$ is also $1 \mathrm{M}$. Therefore, their $\mathrm{pH}$ and $\mathrm{pOH}$ are equal. The $\mathrm{pH}$ of lemon juice is smaller than eight, which means the $\mathrm{pH}$ of lemon juice is higher than water and the molarity of $\mathrm{HCl}$.

When the students' data were analyzed, it was observed that eight of the 27 students had the idea that the " $\mathrm{pH}$ of strong acids is the lowest 
every time," while two of the 27 students had the idea that "strong acids have a high $\mathrm{pH}$." Furthermore, four of the 27 students wrote the idea that the "substance is strong to the extent to which it is burning," while one of the 27 students mentioned the idea that "different acids which have equal concentration have equal $\mathrm{pH} . "$

In the explanation section, while the students considered the results of prediction and observation, they also explained the $\mathrm{pH}$ concept in relation to strength. As well, some students wrote the following explanations in this section:

It did not reconcile. I made a sequence, but its $\mathrm{pH}$ order is wrong. The substance which has a lower $\mathrm{pH}$ is strong.' 'My prediction and observation gave the same result. $\mathrm{HCl}$ is a strong acid. That is why the $\mathrm{pH}$ is very low. Water is neutral and a very weak acid that is why its $\mathrm{pH}$ is very high.' 'The characteristics of the $\mathrm{pH}$ of tap water should be close to neutral. I could not think of why. Anyway, a substance people use much more cannot have much acidity.

Findings Related to the Second POE Task. In this POE task, the students were required to predict the sequence of the $\mathrm{pOH}$ for soap, $1 \mathrm{M} \mathrm{KOH}$, and tap water. While 22 of the 27 students made a correct prediction, most of the students could only express the reason for the prediction according to the partially correct category, as shown in Table 2.

The following statements belong to some students in the sample who have certain misunderstandings and alternative concepts. In addition, these statements show their predictions related to the concepts which were taken into account:

TABLE 2

Students' prediction and reason for their prediction in the POE Tasks

\begin{tabular}{llllllll}
\hline \multicolumn{7}{c}{ Students' predictions and reason of their prediction } \\
\hline Tasks & CP- & CP- & CP- & WP- & WP- & WP- & Total student \\
& CERP & PCERP & WERP & CERP & PCERP & WERP & number \\
\hline 1. POE tasks & 1 & 18 & 2 & 0 & 4 & 2 & 27 \\
2. POE tasks & 0 & 21 & 1 & 0 & 3 & 2 & 27 \\
3. POE tasks & 9 & 10 & 3 & 2 & 1 & 2 & 27 \\
\hline
\end{tabular}

$C P$-CERP correct prediction-correct explanation for reason for prediction, CP-PCERP correct prediction-partially correct explanation for reason for prediction, $C P$ - WERP correct prediction-wrong explanation for reason for prediction, $W P-C E R P$ wrong prediction-correct explanation for reason for prediction, $W P-P C E R P$ wrong prediction-partially correct explanation for reason for prediction, $W P$ $W E R P$ wrong prediction-wrong explanation for reason for prediction 
I did my assessments considering that soap is a chemical substances and it is close to the acidic and basic line.' ' $\mathrm{KOH}$ is a strong base; therefore, it has a higher $\mathrm{pOH}$, lower $\mathrm{pH}$.' 'The $\mathrm{pH}$ of bases are higher than 7, $\mathrm{pH}>7$. If a substance has a higher $\mathrm{pOH}$, it has a lower $\mathrm{pH}$. Soap and $\mathrm{KOH}$ are bases; because $\mathrm{KOH}$ is a stronger base than soap, therefore, the $\mathrm{pOH}$ of $\mathrm{KOH}$ is higher than soap.

When the students' written responses related to POE were analyzed, it was seen that seven of the students wrote that "The $\mathrm{pOH}$ of a strong acid is always small (lower)." However, two students had a different idea, such as "strong bases have a bigger (higher) pOH."

The students' responses related to the explanation section were to

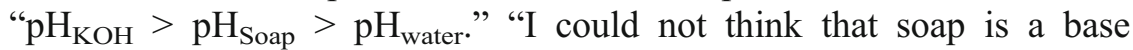
because of its density." "My prediction and observation did not fit each other. I guess, I should study the $\mathrm{pH}$ and $\mathrm{pOH}$ concepts a little bit more. The substance, which has a low $\mathrm{pOH}$, is stronger than the others. I replied to this without thinking. I guess I am confused because of thinking of acids first." "The $\mathrm{pH}$ metre showed that the highest $\mathrm{pH}$ belonged to $\mathrm{KOH}$, then, soap and finally water. I showed this like that. My prediction became true."

Findings Related to the Third POE Task. In the last POE task, the students were asked to predict the $\mathrm{pH}$ of diluted $1 \mathrm{M} \mathrm{HCl}$ which was diluted from 1 to $10 \mathrm{ml}$. As seen in Table 2, 22 of the 27 students stated that once the solution of $1 \mathrm{ml} 1 \mathrm{M} \mathrm{HCl}$ was diluted to $10 \mathrm{ml}$, the $\mathrm{pH}$ of the solution would increase, while four of the 27 students indicated that the $\mathrm{pH}$ of the solution would decrease. Furthermore, one of the 27 students stated that the $\mathrm{pH}$ of the solution would not change.

While 13 of the 27 students predicted that the $\mathrm{pH}$ of a new solution was directly or indirectly related to the concentration of $\left[\mathrm{H}^{+}\right]$, ten students who made the correct prediction explained that the concentration was the reason for the increase of the $\mathrm{pH}$. Given below are the statements of some students in the sample who had misunderstandings and alternative concepts related to the $\mathrm{pH}$ concept.

$\mathrm{HCl}$ decreases, but the $\mathrm{pH}$ of it does not change. In my opinion, it is not in regards to the amount, but the type.' 'If we add some water to $\mathrm{HCl}$, it shows a less burning character because, water has a value that is close to neutral, if it is added as a $\mathrm{pH}$, their common $\mathrm{pH}$ increases.' 'When the value of the $\mathrm{pH}$ increases, the value of the acidity decreases. Water has a value that is close to neutral because of burning less.' 'In my opinion there is no importance of the $\mathrm{HCl}$. I mean, the solution is under the effect of the $\mathrm{HCl}$, so, it increases.' 'The $\mathrm{pH}$ of water is close to neutral. When water and $\mathrm{HCl}$ are mixed, the $\mathrm{pH}$ of $\mathrm{HCl}$ increases. When the $\mathrm{pH}$ of the $\mathrm{HCl}$ solution is $0,5\left(\mathrm{pH}_{\mathrm{HCI}}=0,5\right)$, if it is mixed with water $\left(\mathrm{pH}_{\mathrm{HCl}}+\mathrm{su}\right)$, its $\mathrm{pH}$ has a value between $0,5-8$. 
When the students' statements related to the explanation sequence were analyzed, it was observed that some of the students who did not make a correct prediction continued their wrong understanding, even if they observed the tasks. While some of the other students changed their ideas. Given below is an example of some of the statements of the students:

It is wrong, but according to me it should not have changed. The $\mathrm{pH} 0.5$ became $\mathrm{pH} 1$. It increased.' ' My prediction and observation did not fit. I guess, I don't know how to use a pH ruler.' 'My predictions are correct because when I completed the numerical operation, it became correct.' 'I mean the pH has increased. It became correct.

\section{Findings Obtained from Interviews}

The findings gathered from the analysis of the interviews of the six students are represented in this section, and a summary of the findings is presented in Table 3 . When Table 3 was analyzed, it was observed that most of the students thought that $\mathrm{pH}$ was only related to acids, while students $\mathrm{B}$ and $\mathrm{F}$ mentioned that it was related to both acidity and basicity. While the students explained that the concept of $\mathrm{pH}$ was related

TABLE 3

Students' opinions related to the $\mathrm{pH}$ concept

\begin{tabular}{|c|c|c|}
\hline \multirow[b]{2}{*}{ SPI } & \multicolumn{2}{|l|}{ pH concept } \\
\hline & Students' understanding related to $\mathrm{pH}$ & Solution which has a $\mathrm{pH} 12$ \\
\hline A & Related to acidity & $\begin{array}{l}\text { I know that it is a base because if a } \\
\text { substance has } \mathrm{pH} 8 \text { it shows its basicity }\end{array}$ \\
\hline B & $\begin{array}{l}\text { It gives an idea related to how a substance is a strong } \\
\text { acid or strong base }\end{array}$ & It shows a basic character \\
\hline $\mathrm{C}$ & $\begin{array}{l}\text { As I said before, a substance which has a lower } \mathrm{pH} \\
\text { has higher acidity } \\
\text { We did some algebraic operations in order to find the } \\
\text { ion concentration of }\left[\mathrm{H}^{+}\right] \text {. pH multiplied by } \mathrm{pOH} \\
\text { equals } 14 \text {. I know something related to operational } \\
\text { things }\end{array}$ & It shows a basic character after $\mathrm{pH} 7$ \\
\hline $\mathrm{D}$ & $\begin{array}{l}\text { For example if a solution is acidic, its } \mathrm{pH} \text { is lower } \\
\text { than } 7 \text {. If it is equal to } 7 \text {, it is neutral and if its } \mathrm{pH} \text { is } \\
\text { higher than } 7 \text {, it is basic }\end{array}$ & $\begin{array}{l}\text { It has a basic solution. It has more than } \\
\mathrm{OH}^{-} \text {ion }\end{array}$ \\
\hline $\mathrm{E}$ & Its acidic character is coming to my mind & It is a strong base when its $\mathrm{pH}$ is 12 \\
\hline $\mathrm{F}$ & $\begin{array}{l}\text { It shows the scale of an acidic and basic character. } \\
\mathrm{pH} \text { is generally used for acids and } \mathrm{pOH} \text { used for } \\
\text { bases. These two are opposite of each other } \\
\text { It has a lower acidity whose } \mathrm{pH} \text { is high }\end{array}$ & They did not give any idea \\
\hline
\end{tabular}

SPI students who participated in an interview 
to an increasing or decreasing of acidity or basicity, student $\mathrm{D}$ mentioned that if the $\mathrm{pH}$ became lower than 7, the ion concentration of the hydrogen in the solution would become higher, as shown in the table. Thus, the higher the ion concentration in the solution, the higher was the acidity in the solution. In the interview, approximately all students gave the answer as being the basic solution to the question related to a substance that has a $\mathrm{pH}$ that equals 12 .

It can be seen in Table 4 that the pOH concept provides the students ideas related to the basicity of the environment. While student A explained the pOH concept as "a concept which is related to basicity: it is related to the molarity of the $\mathrm{OH}^{-}$ion," which means that it is related to the ion concentration of $\left[\mathrm{OH}^{-}\right]$, the other students stated that $\mathrm{pOH}$ was the concept that explained the increasing or decreasing of basicity. Alternatively, while a majority of the students stated that a substance whose $\mathrm{pOH}$

TABLE 4

Students' opinions related to the pOH concept and concept of strength

\begin{tabular}{|c|c|c|c|c|}
\hline \multirow[b]{2}{*}{$S P I$} & \multicolumn{2}{|l|}{ pOH concept } & \multicolumn{2}{|l|}{ Concept of strength } \\
\hline & $\begin{array}{l}\text { Students' understanding } \\
\text { related to the pOH concept }\end{array}$ & Solution whose $\mathrm{pOH}$ is 9 & $\begin{array}{l}\text { Students' } \\
\text { understanding } \\
\text { related to strength }\end{array}$ & $\begin{array}{l}\text { pH of a } \\
\text { strong acid }\end{array}$ \\
\hline A & $\begin{array}{l}\text { Concepts related to } \\
\text { basicity and related to the } \\
\text { ion concentration of } \mathrm{OH}^{-}\end{array}$ & It is becoming acid & Acids such as $\mathrm{HCl}$ & $\begin{array}{l}\text { It is between } \\
4 \text { and } 5\end{array}$ \\
\hline B & $\begin{array}{l}\text { A pOH of between } 0 \text { and } 7 \\
\text { shows a basic property }\end{array}$ & It is acidic & $\begin{array}{l}\text { Strong acid ionizes } \\
\text { completely }\end{array}$ & It is low \\
\hline $\mathrm{C}$ & $\begin{array}{l}\text { The lowest pOH, The } \\
\text { highest basicity }\end{array}$ & $\begin{array}{l}\text { I just wanted to explain this } \\
\text { with } \mathrm{pH} \text {. If the } \mathrm{pOH} \text { is } 9 \text {, its } \\
\mathrm{pH} \text { is } 5 \text {. It means it shows an } \\
\text { acidic property }\end{array}$ & $\begin{array}{l}\text { It is strong if it has a } \\
\text { lower } \mathrm{pH}\end{array}$ & $\begin{array}{l}\text { It is a strong } \\
\text { acid whose } \\
\mathrm{pH} \text { is } 1 \text { or } 2\end{array}$ \\
\hline $\mathrm{D}$ & $\begin{array}{l}\text { If its basicity is more, its } \\
\text { pOH is less }\end{array}$ & $\begin{array}{l}\text { Because its pOH is } 9 \text {, its } \mathrm{pH} \\
\text { is } 5 \text {, it is acidic. The ion } \\
\text { concentration of } \mathrm{OH}^{-} \text {is less } \\
\text { than the ion concentration of } \\
\mathrm{H}^{+}\end{array}$ & $\begin{array}{l}\text { The ion } \\
\text { concentration of } \mathrm{H} \\
\text { of a strong acid is } \\
\text { higher }\end{array}$ & $\begin{array}{l}\text { The pH } 4 \text { is } \\
\text { close to } \\
\text { being the } \\
\text { most } \\
\text { powerful }\end{array}$ \\
\hline $\mathrm{E}$ & It shows a basic character & It is a weak base & $\begin{array}{l}\text { Acids which have a } \\
\text { small pH }\end{array}$ & $\begin{array}{l}\text { When the } \mathrm{pH} \\
\text { is } 2, \text { it is } \\
\text { strong }\end{array}$ \\
\hline $\mathrm{F}$ & $\begin{array}{l}\text { Base comes to my mind. It } \\
\text { is a meter like a } \mathrm{pH} \text { meter. } \\
\text { It measures both acidity } \\
\text { and basicity }\end{array}$ & It is acidic & $\begin{array}{l}\text { Strong acid gives a } \\
\text { dark color with } \\
\text { litmus paper, it } \\
\text { destroys the cloth }\end{array}$ & $\begin{array}{l}\text { If the } \mathrm{pH} \text { is } \\
1 \text {, it means it } \\
\text { is strong }\end{array}$ \\
\hline
\end{tabular}

SPI students who participated in an interview 
was nine showed a basic property, only student $\mathrm{E}$ mentioned that this substance could be a weak base.

While a majority of the students gave examples of a strong acid or strong base, a small number of students made some comments related to the strength, as seen in Table 4. Besides, when students were asked the $\mathrm{pH}$ of a weak acid, the majority of students made certain comments about this. Students thought that if an acid has a lower $\mathrm{pH}$, it means that the acid is a strong acid. Student B mentioned that "strong acids ionize completely," "weak acids ionize partially. It balances with its solid because of ionizing partially. It does not give away ions completely." Student D explained their ideas as, " $\left[\mathrm{H}^{+}\right]$ion concentration is higher than the others in a strong acid." In the drawings that students had done during the process of the interviews, it was revealed that a great number of students drew strong acids as if they have more $\mathrm{H}^{+}$ions, while weak acids were seen to have less $\mathrm{H}^{+}$. Furthermore, it was observed that some students decided on whether a substance was acid or not by looking at the color of the indicator. Therefore, student B stated that "If we look at the $\mathrm{pH}$, its colour is changing from dark to light. If we look at the $\mathrm{pOH}$, its colour is changing from light to dark." It is understood that student $\mathrm{B}$ had a similar idea to student $\mathrm{F}$ in relation to a strong acid, whereby the color of the indicator changes to a darker color. Also, students A and B explained the concept of strength as the idea of edible or drinkable. In this context, student B stated their ideas as "We cannot eat strong acid. The $\mathrm{pH}$ of lemon was around 2.5. It is considered as strong, but we cannot eat HCl."

\section{Discussion and Conclusions}

When the students' written responses related to the POE tasks were analyzed, it was observed that a majority of the students concluded that the $\mathrm{pH}$ was related to the acids, while the $\mathrm{pOH}$ was related to bases. The above-mentioned information was also reported in the studies of Zoller (1990) and Canpolat (2004). When the students' interviews were analyzed, the following information about a substance was deduced: A substance which has a higher $\mathrm{pH}$ indicates a basic property, while a substance which has a higher $\mathrm{pOH}$ has an acidic property. It was observed that when the students were asked a question related to the $\mathrm{pOH}$, they made more errors in accordance with the $\mathrm{pH}$ concept. Both the textbooks and the objectives of the curriculum were analyzed in terms of the examples of acids and bases. It was observed that acids took up more place than bases, and the $\mathrm{pH}$ concept had more emphasis than the $\mathrm{pOH}$. When the students were asked a question related to which substance had a 
higher $\mathrm{pOH}$, nearly all of them responded by using the equation, $\mathrm{pH}+\mathrm{pOH}=14$. Generally, the students preferred to reverse the $\mathrm{pOH}$ to $\mathrm{pH}$ and then explain the acidic or basic character of the substance. As well, the students did not mention the conceptual explanation of both the concepts. In other words, the students expressed both the concepts by using an algebraic explanation rather than a conceptual explanation (Smitz and Metz, 1996). This could be a result of the University Entrance Exam, whereby the teachers may prefer to explain the topic by using an algebraic explanation.

Although the students who participated in the first and second POE tasks related to the ordering of $\mathrm{pH}$ and $\mathrm{pOH}$ produced a correct prediction as to the ordering, only some of these students could explain the correct reason of the prediction. A majority of the students expressed their answers as "strong acids always have a low $\mathrm{pH}$," as seen in the abovementioned explanation. This result is also supported in the related literature (Demircioğlu, Özmen \& Ayas, 2001; Demircioğlu, Ayas \& Demircioğlu, 2005; Boz, 2009).

In the interview of student $\mathrm{B}$, information about $\mathrm{pH}$ was stated as "It gives an idea to the extent as to which a substance is a strong acid or strong base." The above-mentioned explanation confirmed the students' misunderstandings, which emerged in the POE tasks. The reason for the students' misconceptions is related to the idea that the $\mathrm{pH}$ gave an idea of the strength of the acid and base, which stemmed from students' understanding related to $\mathrm{pH}$ and $\mathrm{pOH}$. While the students mentioned both the concepts, they were just interested in their concentration. On a third of the POE tasks, which probed the relationship between $\mathrm{pH}$ and concentration, it was determined that 13 of the 27 students calculated the $\mathrm{pH}$ considering the ion concentration of $\mathrm{H}^{+}$, while the rest of the students gave different reasons as to the explanation. It is important to focus on the strength when considering the strong and weak acids and bases, which have the same concentration. Although the students were given the concentration of the acids and bases in the POE tasks, they just associated these with the concentration, which could have stemmed from the students' misconceptions or could have been a result of the class instructions (Ross \& Munby, 1991; Bradley \& Mosimege, 1998; Geban, Ertepinar \& Topal, 1998).

The study by Ross \& Munby(1991), which was related to ions, bases, neutralization, $\mathrm{pH}$, and acid-base phenomenon, determined that the students had misconceptions, such as "A strong acid has a higher $\mathrm{pH}$ than a weak acid." In the present study, the students' answers, such as " $\mathrm{HCl}$, like its name, completely shows an acidic character and that is why 
it has a high $\mathrm{pH}$ " and " $\mathrm{HCl}$ is strong acid that is why its $\mathrm{pH}$ is the highest," are similar to those in the literature. Besides, the students' answers, such as " $\mathrm{KOH}$ is a strong base. Its $\mathrm{pOH}$ is the highest. Soap is also a base....," "Soap and $\mathrm{KOH}$ are both bases, but $\mathrm{KOH}$ is stronger than the other and that is why its $\mathrm{pOH}$ is higher," and " $\mathrm{KOH}$ is a strong base and that is why its $\mathrm{pOH}$ is the highest and the $\mathrm{pH}$ is the smallest," show similarities to the study of Morgil et al. (2003). In the above-mentioned study, in relation to $\mathrm{pOH}$, it was reported that a strong base is the base which has the higher $\mathrm{pOH}$.

When the findings related to the students' drawings, gathered during the process of interviews, were analyzed, it was determined that the students had some understanding, such as the "ion concentration of $[\mathrm{H}]^{+}$ is higher for strong acids" and the "ion concentration of $[\mathrm{H}]^{+}$is lower for weak acids." This idea could be a result of the students' understanding of the concentration of $\left[\mathrm{H}^{+}\right]$or $\left[\mathrm{OH}^{-}\right]$, which became the determining factor for deciding the strength.

Even though the students could easily provide examples of strong acids and strong bases, very few students could make a commitment with respect to the strength. The students' answers, such as "The ion concentration of a strong acid is high" and "We said that $\mathrm{HCl}$ has $1 \mathrm{M}$, and then I thought that water has $1 \mathrm{M}$. If the molarity is the same, at that time they will have an equal $\mathrm{pH}$ value," showed similarities to the results of the study of Ross \& Munby (1991). It was reported that the concentration and the strength were the same thing for some of the students.

One of the students' misconceptions, observed from the analysis of the interview data and the students' written responses to the POE, was related to dissolubility and ionization. In the interview of student $\mathrm{B}$, it was mentioned that the strong acid ionized completely, while the weak acid ionized partially. Thus, it was in a balance with its solid and did not give up the ion completely. Some of the students believed that "The ion concentration of weak acids is less because of less dissolution." It is understood that the source of this misconception could be a result of believing that "substances which cannot ionize, do not dissolve," which is related to dissolubility.

In the interview with student $\mathrm{F}$, it was mentioned that "for example, we can observe it with litmus paper in terms of its colour. $\mathrm{HCl}$ breaks the fabric into pieces, but lemon does not show the same effect." In this context, student B stated the same things. Both the students explained the strength of the acid with regards to the color or by its breaking the fabric into pieces. The obtained results had similarities to the study of Bradley \& 
Mosimege (1998), which reported the use of an indicator to understand the strength of an acid.

In this study, POE evaluation criteria were used to gauge students' understanding levels related to the concepts being investigated. In the literature, POE tasks were generally evaluated using students' interviews during the implementation of tasks (Kearney et al., 2001; Kearney \& Treagust, 2001; Kearney, 2004; Russell, Lucas \& McRobbie, 1999, 2003, 2004; Tao \& Gunstone, 1999; Monaghan \& Celement, 1999). However, in this study, a systematic way for evaluating students' understanding levels, in terms of prediction and reason of prediction sequences, were offered. As seen in the findings, teacher can easily see how many students have the correct understanding, partially correct understanding, or wrong understanding. Teachers might choose to give scores to this understanding level in prediction and reasons for prediction sequences, such as a two tier test (White \& Gunstone, 1992). In this study, students' understanding levels were determined without giving any scores to them.

\section{IMPLICATIONS AND RECOMMENDATIONS}

The purpose of the present study was to investigate the high school students' conceptions and misconceptions about $\mathrm{pH}-\mathrm{pOH}$ and the strength of acids, as well as how this concept was constructed in their minds at the micro and macro levels. The results of the present study revealed that the majority of the students had misconceptions related to these three concepts. The students had a number of common misconceptions concerning the topic of acids and bases. Thus, the teachers should take these topics into consideration while teaching acid-base chemistry, together with the related concepts. In the present study, it is recommended that while teaching secondary science, the students' previous knowledge should be considered for more meaningful learning. Besides the textbooks and materials used in the classroom, teachers should consider the students' understanding at the microscopic level.

POE tasks used in this study were chosen from everyday life examples of acids and bases. Chemistry teachers can prepare these tasks easily and in a short time in their classrooms. Hence, these tasks are examples of how the POE technique can be replicated effectively in classes. The other conclusion that emerged from the study is that students' understanding levels in the prediction and the reason for prediction sequences were determined explicitly with the evaluation criteria for POE. It is a known fact that classical multiple choice tests are generally used for determining 
students' conceptual understanding. When students were given multiple choice exams, students could find the correct choices by chance, so sometimes it is difficult to determine if students' are understanding effectively because of students' anxiety levels in the test. However, POE is one of the techniques that has enabled the students to rise up again in their understanding without being anxious. This study suggested that the POE technique can evaluate students' understanding level. In addition, these understanding levels can be given certain scores to measure students' achievement levels.

In the present study, the data collection instruments were used as an assessment method because the study was done at the end of the instruction/ on the acid and base topics. The POE tasks, interviews, and drawings were used for a few concepts, such as the $\mathrm{pH}, \mathrm{pOH}$, and strength. It has been recommended that the use of the POE tasks on a broader range of concepts concerning acids and bases could be more efficient in the teaching and assessing the sections of topics in secondary classrooms. Besides, it could also be useful to perform the POE tasks with computer animation and simulations for a better knowledge of the students' understanding and misconceptions regarding the topics of chemistry.

\section{REFERENCES}

Abraham, M. R., Grzybowski, E. B., Renner, J. W. \& Marek, E. A. (1992). Understandings and misunderstandings of eighth graders of five chemistry concepts found in textbooks. Journal of Research in Science Teaching, 29, 105-120.

Abraham, M. R., Williamson, V. M. \& Westbrook, S. L. (1994). A cross-age study of the understanding of five chemistry concepts. Journal of Research in Science Teaching, 31, $147-165$.

Ayas, A., Özmen, H. \& Çalık, M. (2010). Students' conceptions of the particulate nature of matter at secondary and tertiary level. International Journal of Science and Mathematics Education, 8(1), 165-184.

Banerjee, A. C. (1991). Misconceptions of students and teachers in chemical equilibrium. International Journal of Science Education, 13, 487-494.

Banerjee, A. C. (1995). Teaching chemical equilibrium and thermodynamics in undergraduate general chemistry classes. Journal of Chemical Education, 72, 879-881.

Bassey, M. (1999). Case study research in educational settings. Buckingham, UK: Open University Press.

Boz, Y. (2009). Turkish prospective chemistry teachers' alternative conceptions about acids and bases. School Science and Mathematics Journal, 109(4), 212-222.

Bradley, J. D. \& Mosimege, M. D. (1998). Misconceptions in acids and bases: A comparative study of student teachers with different chemistry backgrounds. South African Journal of Chemistry, 51, 137-147.

Canpolat, N., Pınarbașı, T., Bayrakçeken, S. \& Geban, Ö. (2004). Some common misconceptions in chemistry. Journal of Gazi Faculty of Education, 24(1), 135-146. 
Champagne, A. B., Klopher, L. \& Anderson, J. (1980). Factors influencing the learning of classical mechanics. American Journal of Physics, 48(12), 1074-1079.

Coll, R. K. \& Treagust, D. F. (2003). Investigation of secondary school, undergraduate and graduate learners' mental models of ionic bonding. Journal of Research in Science Teaching, 40, 464-486.

Cros, D., Maurin, M., Amouroux, R., Chastrette, M., Leber, J. \& Fayol, M. (1986). Conceptions of first year university students of the constituents of matter and the notions of acids and bases. European Journal of Science Education, 8, 305-313.

Demircioglu, G., Ayas, A. \& Demircioglu, H. (2005). Conceptual change achieved through a new teaching programme on acids and bases. Chemistry Education: Research and Practice, 6, 36-51.

Demircioğlu, G., Özmen, H. \& Ayas, A. (2001). Kimya ögretmen adaylarının asitler ve bazlarla ilgili yanlış anlamalarının belirlenmesi. Maltepe Üniversitesi Eğitim Fakültesi Yeni Binyılın Başında Türkiye'de Fen Bilimleri Eğitimi Sempozyumu Bildiri Kitabı. Istanbul: Marmara Eğitim Vakfi Yayınları, pp. 451-457.

Driver, R. \& Scott, P. (1996). Curriculum development as research: A constructivist approach to science curriculum development and teaching. In D. F. Treagust, R. Duit \& B. J. Fraser (Eds.), Improving teaching and learning in science and mathematics (pp. 94-108). New York: Teachers College Press.

Duit, R., Treagust, D. \& Mansfield, H. (1996). Investigating student understanding as a prerequisite to improving teaching and learning in science and mathematics. In D. F. Treagust, R. Duit \& B. J. Fraser (Eds.), Improving teaching and learning in science and mathematics (pp. 17-31). New York: Teachers College Press.

Ebenezer, J. V. (2001). A hypermedia environment to explore and negotiate students' conceptions: Animation of the solution process of table salt. Journal of Science Education and Technology, 10(1), 73-92.

Gamett, P. J. \& Treagust, D. F. (1992). Conceptual difficulties experienced by senior high school students in electrochemistry: Electrochemical (galvanic) and electrolytic cells. Journal of Research in Science Teaching, 29, 1079-1099.

Geban, Ö., Ertepınar, H., Topal, T., \& Önal, A.M., (1998). Asit-Baz Konusu ve Benzeşme Yöntemi. III. Ulusal Fen Bilimleri Eğitimi Sempozyumu, 23-25 Eylül, Bildiriler Kitabı.s. KTÜ, Trabzon, pp. 176-178.

Griffiths, A. K. \& Preston, K. R. (1992). Grade 12 students' misconceptions relating to fundamental characteristics of atoms and molecules. Journal of Research in Science Teaching, 29, 611-628.

Gunstone, R. Champagne, A. Klopfer, L. (1981). Instruction for understanding: A case study. Australian Science Teachers' Journal, 27(3), 27-32.

Gussarsky, E. \& Gorodetsky, M. (1990). On the concept "chemical equilibrium": The associative framework. Journal of Research in Science Teaching, 27, 197204.

Kearney, M., 2002. Classroom use of multimedia-supported predict-observe-explain tasks to elicit and promote discussion about students' physics concepts. Ph.D. dissertation, Curtin University of Technology, Australia.

Kearney, M. (2004). Classroom use of multimedia-supported predict-observe-explain tasks in a social constructivist learning environment. Research in Science Education, $34,427-453$.

Kearney, M. \& Treagust, D. F. (2001). Constructivism as a referent in the design and development of a computer programme which uses interactive digital video to 
enhance learning in physics. Australian Journal of Educational Technology, 17(1), 64-79.

Kearney, M., Treagust, D., Shelley, Y. \& Zadnik, M. (2001). Student and teacher perception of the use of multimedia supported predict-observe-explain task to probe understanding. Research in Science Teaching, 31, 539-615.

Lin, J. W., Chiu, M. H., \& Liang, J. C. (2004). Exploring mental models and causes of students' misconceptions in acids and bases. In Paper presented at the National Association for Research in Science Teaching, Vancouver, Canada.

Monaghan, J. \& Celement, J. (1999). Use of a computer simulation to develop mental simulations for understanding relative motion concepts. International Journal of Science Education, 21(9), 921-944.

Morgil, İ., Erdem, E. \& Y1lmaz, A. (2003). Misconceptions in chemistry education. Hacettepe University Journal of Education, 25, 246-255.

Nakhleh, M. B. (1994). Students' models of matter in the context of acid-base chemistry. Journal of Chemical Education, 71, 495-499.

Nakhleh, M. B. \& Krajcik, J. S. (1994). Influence of levels of information as presented by different technologies on students' understanding of acid, base, and $\mathrm{pH}$ concepts. Journal of Research in Science Teaching, 34, 1077-1096.

Özmen, H., Ayas, A. \& Coștu, B. (2002). Determination of the science student teachers' understanding level and misunderstandings about the particulate nature of the matter. Educational Sciences: Theory \& Practice, 2(2), 507-529.

Pınarbaşı, T. (2007). Turkish undergraduate students' misconceptions on acids and bases. Journal of Baltic Science Education, 6(1), 23-34.

Raviola, A. (2001). Assessing students' conceptual understanding of solubility equilibrium. Journal of Chemical Education, 78(5), 629-631.

Ross, B. \& Munby, H. (1991). Concept mapping and misconceptions: A study of high school students' understandings of acids and bases. International Journal of Science Education, 13, 11-23.

Russell, D., Lucas, K., \& Mcrobbie, C. (1999). Microprocessor based laboratory activities as catalysts for student construction of understanding in physics. In The annual meeting of the Australian Association For Research in Education, Melbourne, Australia.

Russell, D. W., Lucas, K. B. \& McRobbie, C. J. (2003). The role of the microcomputerbased laboratory display in supporting the construction of new understandings in kinematics. Research in Science Education, 33(2), 217-243.

Russell, D. W., Lucas, K. B. \& McRobbie, C. J. (2004). Role of the microcomputer-based laboratory display in supporting the construction of new understandings in thermal physics. Journal of Research in Science Teaching, 41(2), 165-185.

Schmidt, H. D. (1991). A label as a hidden persuader: Chemists neutralization concept. International Journal of Science Education, 13, 137-144.

Schmidt, H. J. (1995). Applying the concept of conjugation to the Bronsted theory of acid-base reactions by senior high school students from Germany. International Journal of Science Education, 17, 733-742.

Sheppard, K. (1997). A qualitative study of high school students' pre and post instructional conceptions in acid-base chemistry. Ed. D. thesis, Teachers College, Columbia University, New York.

Sheppard, K. (2006). High school students' understanding of titrations and related acidbase phenomena. Chemistry Education: Research and Practice, 7, 32-45. 
Smith, K. J. \& Metz, P. A. (1996). Evaluating student understanding of solution chemistry through microscopic representations. Journal of Chemical Education, 73, 233-235.

Stake, R. E. (1995). The art of case study research. London: Sage.

Tao, P. K. \& Gunstone, R. (1999). Conceptual change in science through collaborative learning at the computer. International Journal of Science Education, 21(1), 39-57.

White, R. \& Gunstone, R. (1992). Probing understanding. London: The Falmer Press.

Yıldırım, A. \& Şimşek, H. (2006). Qualitative research methods in social sciences (6th ed.). Ankara, Turkey: Seçilen Press.

Yin, R. K. (1994). Case study research: Design and methods (2nd ed.). London: Sage.

Zoller, U. (1990). Student's misunderstanding and misconceptions in college freshman chemistry (general and organic). Journal of Research in Science Teaching, 27(10), 1053-1065.

Nesli Kala

Fatih Faculty of Education

Karadeniz Technical University

Trabzon, Turkey

E-mail:n_kala46@yahoo.com.tr

Fatma Yaman

Faculty of Education

Bozok University

Yozgat, Turkey

E-mail: fatmayaman@ymail.com

Alipaşa Ayas
Faculty of Education
Bilkent University
Ankara, Turkey
E-mail: alipasaayas@yahoo.com 